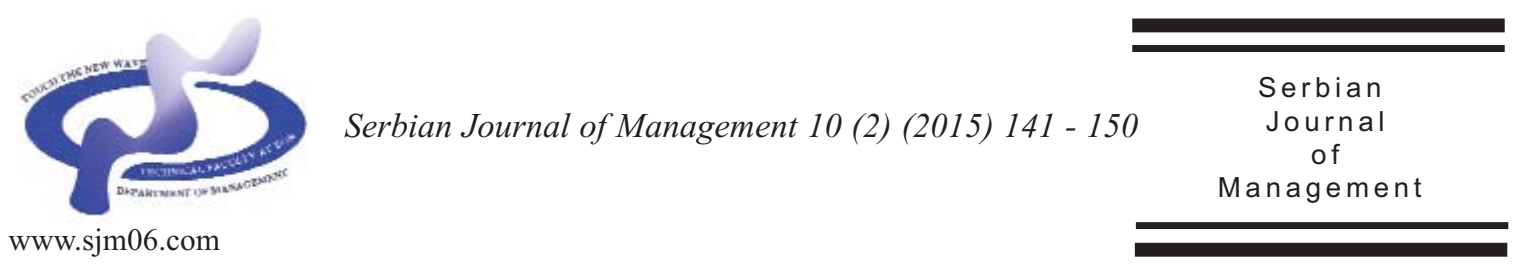

\title{
SWOT - AHP MODEL FOR PRIORITZATION OF STRATEGIES OF THE RESORT STARA PLANINA
}

\author{
Djordje Nikolića , Jelena Spasića Živan Živkovića $^{*}$, Predrag Djordjevića, \\ Ivan Mihajlovića and Jyrki Kangas ${ }^{b}$

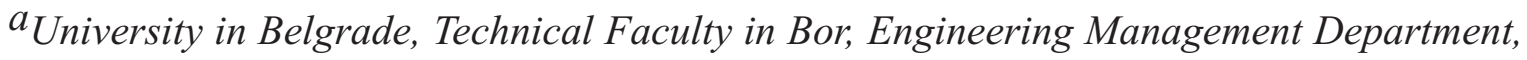 \\ Vojske Jugoslavije 12, 19210 Bor, Serbia

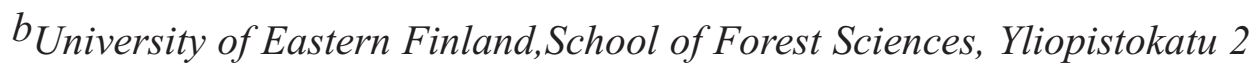 \\ P.O. Box 111, FI-80101 Joensuu, Finland
}

(Received 20 August 2015; accepted 24 September 2015)

\begin{abstract}
This paper presents the results of integrated SWOT analysis and Multi-criteria Decision Analysis (MCDA) model, employed for defining the development of resort Stara Planina in Eastern Serbia and which was based on final report of previous expert study for this touristic destination. In accordance to defined SWOT factors and sub-factors six resulting strategies were generated as: SO strategies (based on the sub-factors of strengths and opportunities), WO strategy (based on the sub-factors of weaknesses and opportunities), ST strategies (based on the sub-factors of strengths and threats) and WT strategy (based on the sub-factors of weaknesses and threats). Relative importance weights of the SWOT factors and sub-factors were obtained by Analytic Hierarchy Process (AHP) model, as well as the ranking of identified strategies was performed by several experts. The results indicate that following sequence of strategies: $\mathrm{SO}_{1} \rightarrow \mathrm{SO}_{2} \rightarrow \mathrm{ST}_{1} \rightarrow \mathrm{ST}_{2} \rightarrow \mathrm{WO}_{1} \rightarrow \mathrm{WT}_{1}$, should be realized to complete the main goals for strategic development of the touristic destination Stara Planina.
\end{abstract}

Keywords: SWOT, AHP, prioritization of strategies, touristic destination, mountain tourism

\section{INTRODUCTION}

Tourism is a growing industry which accounts for 5\% of the world GDP and approximately $30 \%$ of the total export (Antonakakis et al., 2015). Tourism development Strategy of the European Union by 2020 (Lisbon Declaration) predicts the development of different regions in Europe by 2026 with adequate incentives (Sipilko, 2014).

Development of mountain tourist

\footnotetext{
*Corresponding author: zzivkovic@tf.bor.ac.rs

DOI:10.5937/sjm10-8928
} 
destination with year-round activities has been gaining importance in recent years, which is witnessed by a number of projects that are being implemented in South East Europe, especially in Romania and Bulgaria (I ikula et al., 2013).

Tourist destination Stara Planina, located in Eastern Serbia on the border with Bulgaria, is an attractive area with a perspective to enter as a tourist destination on the world tourism scene among relevant tourist sites, if a professional planning and development procedure is carried out in accordance with the rules followed by the similar already renowned destinations, together with the application of the valid quality standards (Bayol et al., 2000; Ghanian et al., 2014).

\section{THEORETICAL FRAMEWORK OF THE RESEARCH}

For the selection and prioritization of the development strategy of the tourist destination Stara Planina, data was gathered from the prefeasibility study on the plan of tourism development in Stara Planina (Horvath, HTL, Zagreb, 2007) and decree of the Government of the Republic of Serbia regarding the program of mountain tourism development in the Stara Planina (S1. Glasnik RS, 2007). From these sources, SWOT analysis of the potential of the Stara Planina was formulated and based on the SWOT factors and sub-factors possible strategies of development of this tourist destination were defined.

Prioritization of possible strategies of development of Stara Planina as a tourist destination was carried out using SWOTAHP (Analytical Hierarchy Process), according to a procedure defined by Kurttila and his associates (Kurttila et al., 2000).

In the academic literature the researches were conducted in order to define the strategy for the development of tourist destinations with different approaches to defining key performances on the basis of the SWOT analysis (Kajanus et al., 2004; Wicraramasinghe \& Takano, 2009; I ered \& Bole, 2009; Bojović \& Plavša, 2011; Jeon \& Kim, 2011; Sariisik et al., 2011; Zhang, 2012; Zhang, 2012; Reihanian, 2012; Bhatia, 2013; Vladi, 2014).

In applying SWOT analysis as a tool for generating and ranking optimal strategies, numerous tools for decision making have been developed recently that broaden its application and create numerous opportunities for making objective decisions. The most commonly used model of multicriteria decision making used to define prioritization of strategies is AHP (Kurttila et al., 2000; Kangas et al., 2001; Kajunus et al., 2004; Osuna \& Aranda, 2007; Ho, 2008; Gorener et al., 2012).

\section{SWOT ANALYSIS OF TOURIST DESTINATION STARA PLANINA AND PRIORITIZATION OF POSSIBLE STRATEGIES}

SWOT analysis for the tourist destination Stara Planina was conducted using workshops with key stakeholders, market analysis, the database and expertise of the Horvath Consulting Zagreb (Horvath, HTL, Zagreb, 2007).

Stara Planina with its surroundings has all the prerequisites to develop a necessary broader tourist destination value chain, modeled on other mountain destinations. Although these potentials are heading towards market resurgence, their real 
business growth will follow only after activation of this tourist mega project. Following steps present the scope of planned activities:

Step 1. Based on the results of SWOT analysis conducted for the case of tourist destination Stara Planina, and by comparing the SWOT factors: strengths, weaknesses, opportunities and threats, as well as the subfactors within each factor, possible strategies for the future development of Stara Planina were defined.

Based on considered objective strengths, weaknesses, opportunities and threats, SWOT criteria were defined within each of these factors and the results are presented in the form of a SWOT matrix in Table 1.

Comparative expert analysis of SWOT factors shown in Table 1 enabled the definition of possible strategies $\mathrm{SO}_{1}$ and $\mathrm{SO}_{2}$ by which potentials of strengths are being used to take advantage of the opportunities which are perceived in the environment. In order to overcome internal weaknesses by using the opportunities in the environment, strategy $\mathrm{WO}_{1}$ was defined. Strategies $\mathrm{ST}_{1}$ and $\mathrm{ST}_{2}$ allow the use of internal strengths to avoid threats. Finally, strategy $\mathrm{WT}_{1}$ allows for reducing the weaknesses in order to avoid threats.

Based on the SWOT-AHP hybrid model for prioritization of the development strategy, on the basis of the results of the SWOT factors, sub-factors, defined strategies and established goal of determining the best strategy, the AHP working model, presented on Figure 1, is used for defining mutual relations between SWOT factors and sub-factors in order to prioritize defined strategies for the development of the tourist destination Stara Planina.

Step 2. Based on the assessment of the expert team, the importance of each of the SWOT factors (criteria) in the model is determined, where their internal interdependence was not taken into consideration but only importance in relation to the set objective within the level 1 SWOT criteria Strengths - S, Weaknesses $\mathrm{W}$, Opportunities - O and Threats - T (see Figure 1). The resulting importance of each SWOT factor is shown in Table 2, where it can be seen that the greatest significance, on

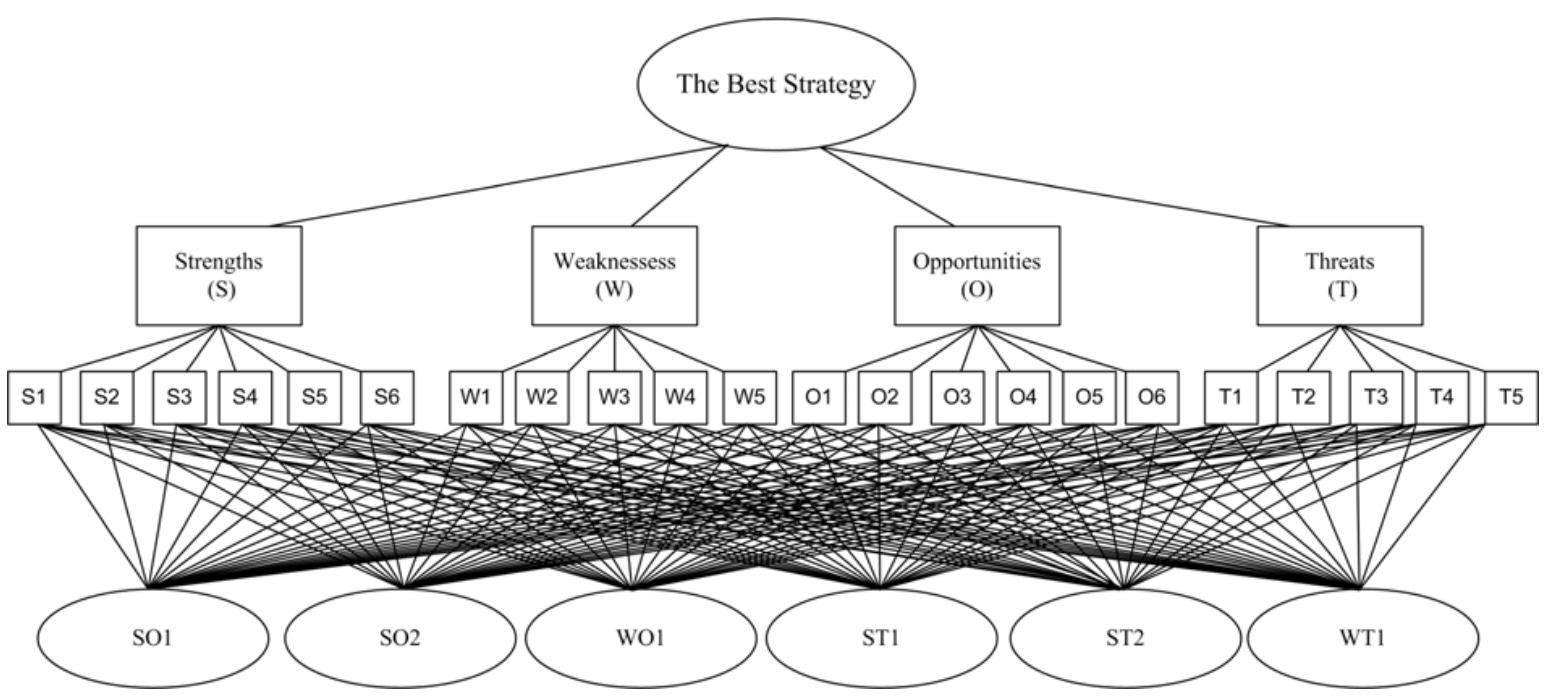

Figure 1. AHP model for the selection of the best strategy 


\section{Table 1. SWOT matrix for the tourist destination Stara Planina}

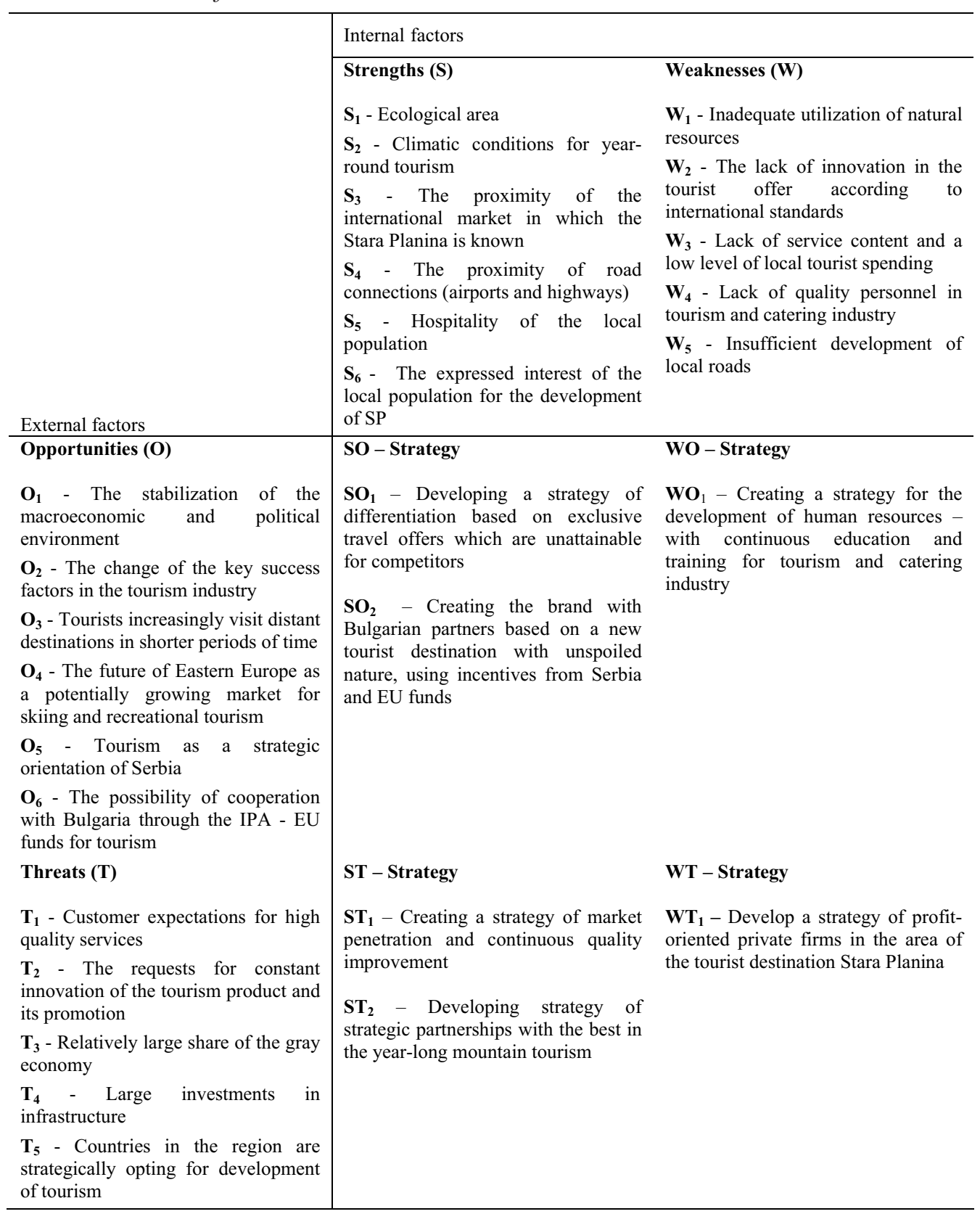

\section{Table 2. Pairwise comparison of the SWOT groups}

\begin{tabular}{lllllc}
\hline SWOT group & $\mathrm{S}$ & $\mathrm{W}$ & $\mathrm{O}$ & $\mathrm{T}$ & $\begin{array}{c}\text { Importance of the } \\
\text { SWOT factor }\end{array}$ \\
\hline Strengths (S) & 1 & 4 & $1 / 2$ & 3 & 0.288 \\
Weaknesses (W) & & 1 & $1 / 7$ & 2 & 0.099 \\
Opportunities (O) & & & 1 & 5 & 0.533 \\
Threats (T) & & & 1 & 0.080 \\
\hline Consistency ratio relative to the goal: $C R=0.049$ & & & &
\end{tabular}

Consistency ratio relative to the goal: $C R=0.049$ 
the basis of evaluation of the expert team, is associated to SWOT factor opportunities (53.3\% significance).

From the previous Table 2, it follows that:

$$
\mathrm{w}_{1}=\left[\begin{array}{c}
\mathrm{S} \\
\mathrm{W} \\
\mathrm{O} \\
\mathrm{T}
\end{array}\right]=\left[\begin{array}{c}
0.288 \\
0.099 \\
0.533 \\
0.080
\end{array}\right]
$$

Table 3. Pairwise comparison of the SWOT sub-criteria - Strengths

\begin{tabular}{llllllll}
\hline Strengths (S) & $\mathrm{S}_{1}$ & $\mathrm{~S}_{2}$ & $\mathrm{~S}_{3}$ & $\mathrm{~S}_{4}$ & $\mathrm{~S}_{5}$ & $\mathrm{~S}_{1}$ & Local weights \\
\hline $\mathrm{S}_{1}$ - Ecological area & 1 & $1 / 4$ & 3 & $1 / 4$ & 5 & 4 & 0.141 \\
$\mathrm{~S}_{2}$ - Climatic conditions for year-round tourism & & 1 & 5 & 3 & 7 & 6 & 0.42 \\
$\mathrm{~S}_{3}-$ The proximity of the international market in & & & 1 & $1 / 4$ & 5 & 4 & 0.096 \\
$\begin{array}{l}\text { which the Stara Planina is known } \\
\mathrm{S}_{4}-\text { The proximity of road connections (airports } \\
\text { and highways) }\end{array}$ & & & 1 & 6 & 5 & 0.267 \\
$\mathrm{~S}_{5}-$ Hospitality of the local population & & & & & 1 & $1 / 2$ & 0.032 \\
$\begin{array}{l}\mathrm{S}_{6}-\text { The expressed interest of the local } \\
\text { population for the development of SP }\end{array}$ & & & & & 1 & 0.044 \\
\hline
\end{tabular}
The consistency ratio in relation to the group Strengths: $C R=0.091$

Table 4. Pairwise comparison of the SWOT sub-criteria - Weaknesses

\begin{tabular}{lcccccc}
\hline Weaknesses $(\mathrm{W})$ & $\mathrm{W}_{1}$ & $\mathrm{~W}_{2}$ & $\mathrm{~W}_{3}$ & $\mathrm{~W}_{4}$ & $\mathrm{~W}_{5}$ & Local weights \\
\hline $\begin{array}{l}\mathbf{W}_{1} \text { - Inadequate utilization of natural } \\
\text { resources }\end{array}$ & 1 & $1 / 6$ & $1 / 2$ & $1 / 6$ & $1 / 6$ & 0.041 \\
$\mathbf{W}_{2}-$ The lack of innovation in the tourist offer & & 1 & 5 & $1 / 4$ & $1 / 3$ & 0.168 \\
$\begin{array}{l}\text { according to international standards } \\
\mathbf{W}_{3} \text { - Lack of service content and a low level }\end{array}$ & & & 1 & $1 / 5$ & $1 / 5$ & 0.060 \\
$\begin{array}{l}\text { of local tourist spending } \\
\mathbf{W}_{4} \text { - Lack of quality personnel in tourism and } \\
\text { catering industry }\end{array}$ & & & 1 & 3 & 0.460 \\
$\mathbf{W}_{5}$ - Insufficient development of local roads & & & & 1 & 0.271 \\
\hline
\end{tabular}

The consistency ratio in relation to the group Weaknesses: $C R=0.093$

Table 5. Pairwise comparison of the SWOT sub-criteria - Opportunities

\begin{tabular}{|c|c|c|c|c|c|c|c|}
\hline Opportunities (O) & $\mathrm{O}_{1}$ & $\mathrm{O}_{2}$ & $\mathrm{O}_{3}$ & $\mathrm{O}_{4}$ & $\mathrm{O}_{5}$ & $\mathrm{O}_{6}$ & Local weights \\
\hline $\begin{array}{l}\mathbf{O}_{1}-\text { The stabilization of the macroeconomic and } \\
\text { political environment }\end{array}$ & 1 & 5 & 3 & 6 & $1 / 3$ & 4 & 0.254 \\
\hline $\begin{array}{l}\mathbf{O}_{2} \text { - The change of the key success factors in the } \\
\text { tourism industry }\end{array}$ & & 1 & $1 / 4$ & 3 & $1 / 6$ & $1 / 3$ & 0.052 \\
\hline $\begin{array}{l}\mathbf{O}_{3} \text { - Tourists increasingly visit distant destinations } \\
\text { in shorter periods of time }\end{array}$ & & & 1 & 5 & $1 / 4$ & 3 & 0.150 \\
\hline $\begin{array}{l}\mathbf{O}_{4} \text { - The future of Eastern Europe as a potentially } \\
\text { growing market for skiing and recreational tourism }\end{array}$ & & & & 1 & $1 / 7$ & $1 / 4$ & 0.031 \\
\hline $\mathbf{O}_{5}$ - Tourism as a strategic orientation of Serbia & & & & & 1 & 5 & 0.426 \\
\hline $\begin{array}{l}\mathbf{O}_{6} \text { - The possibility of cooperation with Bulgaria } \\
\text { through the IPA - EU funds for tourism }\end{array}$ & & & & & & 1 & 0.087 \\
\hline
\end{tabular}

The degree of consistency in relation to the group Opportunities: $C R=0.075$ 
Table 6. Pairwise comparison of the SWOT sub-criteria - Threats

\begin{tabular}{lllllll}
\hline Threats (T) & $\mathrm{T}_{1}$ & $\mathrm{~T}_{2}$ & $\mathrm{~T}_{3}$ & $\mathrm{~T}_{4}$ & $\mathrm{~T}_{5}$ & Local weights \\
\hline $\begin{array}{l}\mathbf{T}_{1} \text { - Customer expectations for high quality } \\
\text { services }\end{array}$ & 1 & 4 & 5 & 6 & 3 & 0.470 \\
$\begin{array}{l}\mathbf{T}_{2}-\text { The requests for constant innovation of the } \\
\text { tourism product and its promotion }\end{array}$ & 1 & 3 & 4 & $1 / 3$ & 0.143 \\
$\mathbf{T}_{3}$ - Relatively large share of the gray economy & & & 1 & 3 & $1 / 4$ & 0.080 \\
$\mathbf{T}_{4}$ - Large investments in infrastructure & & & & 1 & $1 / 5$ & 0.045 \\
$\mathbf{T}_{5}$ - Countries in the region are strategically & & & & & 1 & 0.262 \\
opting for development of tourism & & & & &
\end{tabular}

The degree of consistency in relation to the group Threats: $C R=0.07$

\section{Table 7. The importance of the criteria and sub-criteria of the SWOT analysis}

\begin{tabular}{|c|c|c|c|c|}
\hline $\begin{array}{l}\text { SWOT groups - } \\
\text { criteria }\end{array}$ & $\begin{array}{c}\text { Importance } \\
\text { of the } \\
\text { SWOT } \\
\text { criterion } \\
\end{array}$ & SWOT sub-criteria & $\begin{array}{c}\text { Local } \\
\text { importance of } \\
\text { SWOT sub- } \\
\text { criterion } \\
\end{array}$ & $\begin{array}{l}\text { The overall } \\
\text { importance of } \\
\text { SWOT sub- } \\
\text { criterion }\end{array}$ \\
\hline Strengths - S & 0.288 & $\begin{array}{l}\mathbf{S}_{1}-\text { Ecological area } \\
\mathbf{S}_{2} \text { - Climatic conditions for year-round tourism } \\
\mathbf{S}_{3} \text { - The proximity of the international market } \\
\text { in which the Stara Planina is known } \\
\mathbf{S}_{4}-\text { The proximity of road connections } \\
\text { (airports and highways) } \\
\mathbf{S}_{5}-\text { Hospitality of the local population } \\
\mathbf{S}_{6}-\text { The expressed interest of the local } \\
\text { population for the development of SP }\end{array}$ & $\begin{array}{l}0.141 \\
\underline{\mathbf{0 . 4 2 0}} \\
0.096 \\
0.267 \\
0.032 \\
0.044\end{array}$ & $\begin{array}{l}0.041 \\
0.121 \\
0.028 \\
0.077 \\
0.009 \\
0.013\end{array}$ \\
\hline Weaknesses - W & 0.099 & $\begin{array}{l}\mathbf{W}_{1} \text { - Inadequate utilization of natural resources } \\
\mathbf{W}_{2} \text { - The lack of innovation in the tourist offer } \\
\text { according to international standards } \\
\mathbf{W}_{3} \text { - Lack of service content and a low level of } \\
\text { local tourist spending } \\
\mathbf{W}_{4} \text { - Lack of quality personnel in tourism and } \\
\text { catering industry } \\
\mathbf{W}_{5} \text { - Insufficient development of local roads }\end{array}$ & $\begin{array}{l}0.041 \\
0.168 \\
0.060 \\
\underline{\mathbf{0 . 4 6 0}} \\
0.271\end{array}$ & $\begin{array}{l}0.004 \\
0.017 \\
0.006 \\
0.046 \\
0.027\end{array}$ \\
\hline Opportunities - O & $\underline{0.533}$ & $\begin{array}{l}\mathbf{O}_{1}-\text { The stabilization of the macroeconomic } \\
\text { and political environment } \\
\mathbf{O}_{2}-\text { The change of the key success factors in } \\
\text { the tourism industry } \\
\mathbf{O}_{3} \text { - Tourists increasingly visit distant } \\
\text { destinations in shorter periods of time } \\
\mathbf{O}_{4} \text { - The future of Eastern Europe as a } \\
\text { potentially growing market for skiing and } \\
\text { recreational tourism } \\
\mathbf{O}_{5}-\text { Tourism as a strategic orientation of } \\
\text { Serbia } \\
\mathbf{O}_{6}-\text { The possibility of cooperation with } \\
\text { Bulgaria through the IPA - EU funds for } \\
\text { tourism }\end{array}$ & $\begin{array}{l}0.254 \\
0.052 \\
0.150 \\
0.031 \\
\underline{\mathbf{0 . 4 2 6}} \\
0.087\end{array}$ & $\begin{array}{l}0.135 \\
0.028 \\
0.080 \\
0.017 \\
0.227 \\
0.046\end{array}$ \\
\hline Threats - T & 0.08 & $\begin{array}{l}\mathbf{T}_{1}-\text { Customer expectations for high quality } \\
\text { services } \\
\mathbf{T}_{2}-\text { The requests for constant innovation of the } \\
\text { tourism product and its promotion } \\
\mathbf{T}_{3}-\text { Relatively large share of the gray } \\
\text { economy } \\
\mathbf{T}_{4} \text { - Large investments in infrastructure } \\
\mathbf{T}_{5}-\text { Countries in the region are strategically } \\
\text { opting for development of tourism }\end{array}$ & $\begin{array}{l}\frac{\mathbf{0 . 4 7 0}}{0.143} \\
0.080 \\
0.045 \\
0.262\end{array}$ & $\begin{array}{l}0.038 \\
0.011 \\
0.006 \\
0.004 \\
0.021\end{array}$ \\
\hline
\end{tabular}


Step 3. In this step, local importance of SWOT sub-criteria was determined by the expert team, while the scores of comparative pairs of SWOT sub-criteria, defined in Table 1, are given in tables 3-6.

Step 4. Through mutual multiplying of obtained weight factors from Step 2 and Step 3 , global importance of SWOT sub-criteria is calculated, as presented in Table 7.

The resulting normalized results indicate the dominant influence of the following subcriteria: $\mathrm{S}_{2}$ - Climatic conditions for yearround tourism (0.420), $\mathrm{O}_{5}$ - Tourism as a strategic orientation of Serbia, as positive sub-criteria and $\mathrm{W}_{4}$ - Lack of quality personnel in tourism and catering industry (0.460) and $\mathrm{T}_{1}$ - Customer expectations for high quality services $(0.470)$ as a negative sub-criteria. It is obvious that the strength of the positive sub-criteria is greater than the strength of the negative impact of the subcriteria which is of crucial importance for the choice of the best strategy in the considered case.

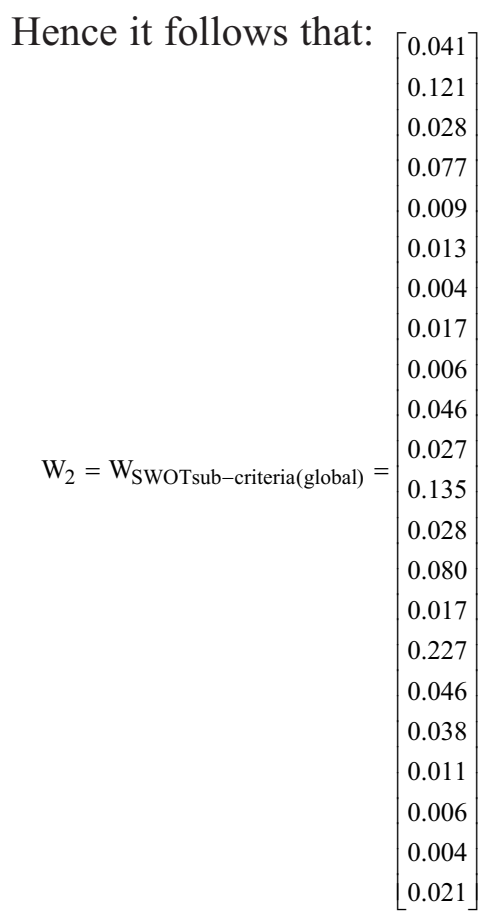

Step 5. In this step, by using expert assessment, the importance weights were determined for each alternative strategy $\left(\mathrm{SO}_{1}, \mathrm{SO}_{2}, \mathrm{WO}_{1}, \mathrm{ST}_{1}, \mathrm{ST}_{2}, \mathrm{WT}_{1}\right)$ relative to the defined SWOT sub-criteria, which resulted in the matrix $\mathrm{W}_{3}$, presented in Table 8.

Step 6. Finally, the overall priority of the considered strategies was calculated as:

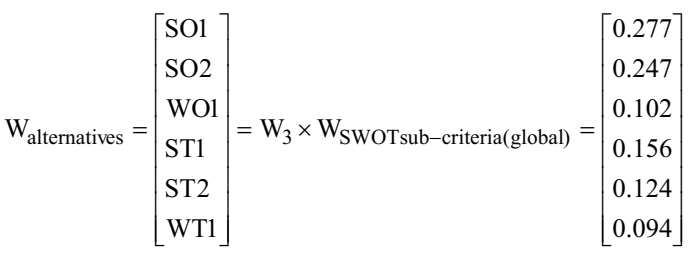

\section{DISCUSSION OF RESULTS}

The results indicate that based on the SWOT-AHP hybrid model, prioritization of the strategies for the development of the tourist destination Stara Planina was defined in the following descending order:

$\mathrm{SO}_{1} \rightarrow \mathrm{SO}_{2} \rightarrow \mathrm{ST}_{1} \rightarrow \mathrm{ST}_{2} \rightarrow \mathrm{WO}_{1} \rightarrow \mathrm{WT}_{1}$

In order for Stara Planina to become a prestigious tourist destination it is necessary to implement the strategy of differentiation $\left(\mathrm{SO}_{1}\right)$ by relying on strengths and the opportunities, which should provide an exclusive offer distinguished by its quality from other tourist centers in the region, in order to attract tourists and earn their loyalty for a return visit. Maintaining a supply to the highest quality standards during a longer period will create conditions for the emergence of the brand together with partners from Bulgaria, using EU funds and government incentives $\left(\mathrm{SO}_{2}\right)$. 
Table 8. Matrix W3 - the importance of the weights determined for each alternative strategy

$\mathrm{W}_{3}=\left[\begin{array}{llllllllllllllllllllll}0.382 & 0.382 & 0.082 & 0.382 & 0.250 & 0.056 & 0.382 & 0.043 & 0.250 & 0.250 & 0.064 & 0.064 & 0.159 & 0.382 & 0.064 & 0.382 & 0.250 & 0.382 & 0.382 & 0.064 & 0.056 & 0.064 \\ 0.250 & 0.250 & 0.380 & 0.250 & 0.160 & 0.052 & 0.250 & 0.160 & 0.042 & 0.160 & 0.043 & 0.382 & 0.101 & 0.160 & 0.382 & 0.250 & 0.382 & 0.250 & 0.250 & 0.043 & 0.039 & 0.043 \\ 0.043 & 0.043 & 0.043 & 0.043 & 0.043 & 0.102 & 0.043 & 0.101 & 0.373 & 0.382 & 0.382 & 0.043 & 0.384 & 0.043 & 0.101 & 0.064 & 0.043 & 0.160 & 0.160 & 0.382 & 0.375 & 0.382 \\ 0.101 & 0.064 & 0.084 & 0.160 & 0.101 & 0.380 & 0.160 & 0.382 & 0.119 & 0.101 & 0.160 & 0.250 & 0.045 & 0.250 & 0.043 & 0.160 & 0.160 & 0.064 & 0.064 & 0.101 & 0.246 & 0.160 \\ 0.160 & 0.160 & 0.250 & 0.101 & 0.382 & 0.250 & 0.101 & 0.250 & 0.105 & 0.064 & 0.250 & 0.160 & 0.062 & 0.101 & 0.250 & 0.043 & 0.101 & 0.101 & 0.101 & 0.160 & 0.156 & 0.250 \\ 0.064 & 0.101 & 0.161 & 0.064 & 0.064 & 0.160 & 0.064 & 0.064 & 0.112 & 0.043 & 0.101 & 0.101 & 0.250 & 0.064 & 0.160 & 0.101 & 0.064 & 0.043 & 0.043 & 0.250 & 0.127 & 0.101\end{array}\right]$

With the implementation of mentioned strategies, the conditions will be created for the application of market penetration strategies $\left(\mathrm{ST}_{1}\right)$ which implies increase in capacity with already achieved level of quality and with trained staff, which then creates prerequisites for the development of the strategy of strategic partnerships with the best in the industry $\left(\mathrm{ST}_{2}\right)$. For the development of the of the abovementioned strategies $\left(\mathrm{ST}_{1}\right)$ and $\left(\mathrm{ST}_{2}\right)$ it is necessary to use EU funds and state subsidies, given that the private sector shows a restraint due to frequent changes in decisions regarding the development of this tourist destination. It is also necessary to simultaneously develop the strategy for the development of human resources consisted of the personal educated for the needs of tourism industry $\left(\mathrm{WO}_{1}\right)$ due to the observed sub-factor $\mathrm{W}_{4}$ - Lack of quality personnel in tourism and catering industry necessary for the development of the mountain destination, which possess the highest value in the sub-factor weaknesses (0.460). Arrival of foreign partners and major players in the tourism sector creates the sense of security in the private sector and primarily in the local population, which would lead to the development of the strategy of profit-oriented private firms $\left(\mathrm{WT}_{1}\right)$.

\section{CONCLUSION}

The achieved results of development of the tourist destination Stara Planina show that initial investments yielded the expected results, which can be confirmed by the significant interest of tourists for a yearround stay on this mountain. However, the planned development was stopped a few years ago due to cessation of any investment even in the maintenance of local roads leading to this destination. Furthermore, the initial enthusiasm of the local population towards investing in the development of this area has also disappeared. Achieved results so far are far from the real potentials of Stara Planina, which indicates that the current development of this tourist destination was not performed according to the requirements in pre-investment study (Horvath, HTL, Zagreb, 2007).

In order to achieve the objectives defined in the pre-investment study (Horvath, HTL, Zagreb, 2007) as well as in the Government's decree on establishing a program for development of mountain tourism in the area of Stara Planina (Sl. Glasnik RS, 2007), the further development of this tourist destination is possible by implementing the highest standards and experiences gained in developing similar destinations. 


\title{
SWОТ-АНР МОДЕЛ ЗА ПРИОРИТИЗАЦИЈУ СТРАТЕГИЈА РАЗВОЈА ТУРИСТИЧКЕ ДЕСТИНАЦИЈЕ СТАРА ПЛАНИНА
}

\author{
Ђорђе Николић ${ }^{\mathrm{a}}$, Јелена Спасић ${ }^{\mathrm{a}}$, Живан Живковић ${ }^{\mathrm{a}}$, Предраг Ђорђевић ${ }^{\mathrm{a}}$, \\ Иван Михајловића и Jyrki Kangas ${ }^{\mathbf{\sigma}}$
}

Извод

У раду је дефинисана "SWOT” анализа за развој туристичке дестинације Стара планина у Источној Србији, на основу експертске прединвестиционе студије развоја ове туристичке дестинације. На основу дефинисаних "SWOT" критеријума и подкритеријума у оквиру дефинисаних критеријума одређене су могуће стратегије на основу “SWOT” критеријума и то: "SO" стратегије (на основу односа снага и шанси); "WO" стратегије (на основу слабости и шансе); "ST" стратегије (на основу снага и претњи) и "WT" стратегије (на основу слабости и претњи). Експертском оценом односа "SWOT” критеријума и подркритеријума коришћењем “AHP (Analytical Hierarchy Process)” методологије, извршена је приоритизација дефинисаних стратегија, при чему је добијен следећи редослед приоритета стратегија: "SO1 $\rightarrow \mathrm{SO} 2 \rightarrow \mathrm{ST} 1$ $\rightarrow \mathrm{ST} 2 \rightarrow \mathrm{WO} \rightarrow \mathrm{WT} 1$ ”, и чијом реализацијом се остварују циљеви развоја туристичке дестинације Стара планина у Источној Србији.

Кључне речи: SWOT, AHP, Приоритизација стратегија, туристичка дестинација, планински туризам

\section{References}

Antonakakis, I ., Dragouni, M., \& Filis, G. (2015). How strong is the linkage between tourism and economic growth in Europe. Economic Modelling, 44, 142-155.

Bayol, M.P., Foye, A., Tellier, C., \& Tenenhaus, M. (2000). Use of PLS path modelling to estimate the European Customer Satisfaction Index (ECSI) model. Statistica Aplicata, 12 (3), 361-375.

Bhatia, A. (2013). SWOT analysis of Indian tourism industry. International Journal of Application or Innovation in Engineering \& Management, 2 (12), 44 - 49.

Bojović, G., \& Plavša, J. (2011). SWOT analysis of tourism on Kopaonik and the spas of its piedmont. Turizam, 15 (3), 109-118.
Ghanian, M., Ghoochani, O.M., \& Crotts, J.C. (2014). An application of European Performance Satisfaction Index toward rural tourism: The case of western Iran. Tourism Management Perspectives, 11, 77-82.

Gorener, A., Toker, K., \& Ulucay, K. (2012). Application of combined SWOT and AHP: A case study for a manufacturing firm. Procedia - Social and Behavioral Sciences, $58,1525-1534$.

Ho, W. (2008). Integrated analytical hierarchy process and its applications - A literature review. European Journal of Operational Research, 186, 211-228.

Horvath, HTL, Zagreb (2007). Plan razvoja turizma na Staroj planini sa predinvesticionom studijom I fizičkotezhničkim karakteristikama skijališta, 1 - 
170.

Jeon, Y.A., \& Kim, J.S. (2011). An application of SWOT -AHP to develop a strategic planning for a tourist destination. Proc. Graduate Students Research Conference, Texas Tech. University, Poster p.7.

Kajanus, M., Kangas, J., \& Kurttila, M. (2004). The use value focused thinking and the A'WOT hybrid method in tourism management. Tourism Management, 25, 499-506.

Kangas, J., Pesonen, M., Kurttila, M., \& Kajanus, M. (2001). A'WOT: Integrating the AHP with SWOT analysis, Proc. 6th ISAHP 2001, Berne, Switzerland, 189 - 198.

Kurttila, M., Pesonen, M., Kangas, J., \& Kajanus, M. (2000). Utilizing the analytic hierarchy process (AHP) in SWOT analysis hybrid method and its application to a forestcertification case. Forest Policy and Economics, 1, 41-52.

I ared, J., \& Bole, D. (2009). CAPACities SWOT analysis, Alpine space programme, Anton Melic Geographical Institute Scientific Research Center of the Slovenian Academy of Sciences and Arts, Ljubljana.

I ikula, V., Spanu, S., \& I eagu, R.E. (2013). Regional tourism development in Romania - consistency with policies and strategies developed at EU level. Procedia Economics and Finance, 6, 530- 541.

Osuna, E.E., \&Aranda, A. (2007). Combining SWOT and AHP techniques for strategic planning. Proc. ISAHP- 2007, Vina del Mar, Chile, 1-8.

Reihanian, A., Mahmood, I .Y.B., Kahrom, E., \& Him, T.W. (2012). Sustainable tourism development strategy by SWOT analysis: Boujagh I ational Park, Iran. Tourism Management Perspectives, 4, 223-228.

Sariisik, M., Turkay, O., \& Akova, O.
(2011). How to manage yacht tourism in Turkey: A swot analysis and related strategies. Procedia Social and Behavioral Sciences, 24, 1014-1025.

Sipilko, D. (2014). The methods used in the construction of a tourism development strategy in the regions. A case study of Poland. Procedia Social and Behavioral Sciences, 156, 157/160.

Sl.Glasnik RS (2007). Uredba o utvrđivanju programa razvoja planinskog turizma na području Stare planine, n0 $85 / 2007$.

Vladi, E. (2014). Tourism Development Strategies, SWOT analysis and improvement of Albania's image. European Journal of Sustainable Development, 3 (1), 167-178.

Wicraramasinghe, V., \& Takano, S. (2009). Application of Combined SWOT and Analytic Hierarchy Process (AHP) for tourism revival strategic marketing planning: A case of Sri Lanka tourism. Journal of the Eastern Asia Society for Transportation Studies, 8, 1-16.

Zhang, Q. (2012). Research on tourism attraction performance promoting method based on the SWOT analysis method. IERI Procedia, 1, 254-260.

Zhang, X.M. (2012). Research on the Development strategies of rural tourism in Suzhou Based on SWOT analysis. Energy Procedia, 16, 1259-1299. 